\title{
Wilms Tumor-1 (WT1) rs16754 Polymorphism
}

\author{
Wilms Tümör-1 (WT1) rs 16754 Polimorfizmi
}

(1) Pathum Sookaromdee ${ }^{1}$, (D) Viroj Wiwanitkit²

${ }^{1}$ TWS Medical Center, Bangkok, Thailand

${ }^{2}$ Dr. DY Patil University, Pune, India

\section{To the Editor,}

The publication "Wilm's tumor-1 (WT1) rs16754 Polymorphism and Clinical Outcome in Acute Myeloid Leukemia" was very interesting [1]. Ramzi et al. [1] noted that "WT1 rs16754 polymorphism may be a reliable independent prognostic factor". In fact, the WT1 rs16754 polymorphism is proposed as an important prognostic marker for leukemia [2]. The application in the present study might be expected. However, there can also be interference effects of other polymorphisms (such as MDM2 [3] and long non-coding RNA GAS5 polymorphism [4]) that were not investigated that might modify the value of WT1 rs 16754 polymorphism testing. Single polymorphism study might limit its application in clinical usage for prognosis prediction for leukemia patients.

Keywords: Wilm's Tumor, gene, polymorphism

Anahtar Sözcükler: Wilms Tümör, gen, polimorfizm
Conflict of Interest: The authors of this paper have no conflicts of interest, including specific financial interests, relationships, and/or affiliations relevant to the subject matter or materials included.

\section{References}

1. Ramzi M, Moghadam M, Cohan N. Wilm's tumor-1 (WT1) rs16754 polymorphism and clinical outcome in acute myeloid leukemia. Turk J Hematol 2019;36:67-68.

2. Petiti J, Rosso V, Lo lacono $M$, Calabrese $C$, Signorino $E$, Gaidano V, Berger M, Saglio G, Cilloni D. Prognostic significance of the Wilms' tumor-1 (WT1) rs16754 polymorphism in acute myeloid leukemia. Leuk Res 2018;67:6-11.

3. He X, Chen P, Yang K, Liu B, Zhang Y, Wang F, Guo Z, Liu X, Lou J, Chen H. Association of MDM2 polymorphism with risk and prognosis of leukemia: a meta-analysis. Acta Haematol 2015;133:365-371.

4. Yan $H$, Zhang DY, Li X, Yuan XQ, Yang YL, Zhu KW, Zeng H, Li XL, Cao S, Zhou HH, Zhang W, Chen XP. Long non-coding RNA GAS5 polymorphism predicts a poor prognosis of acute myeloid leukemia in Chinese patients via affecting hematopoietic reconstitution. Leuk Lymphoma 2017;58:19481957.

${ }^{\circ}$ Copyright 2019 by Turkish Society of Hematology

Turkish Journal of Hematology, Published by Galenos Publishing House 